\title{
Transient elevation of the ipsilateral hemidiaphragm associated with pneumonia
}

\author{
Andrew Fretzayas MD PhD ${ }^{1}$, Maria Moustaki MD PhD ${ }^{1}$, Polyxeni Nicolaidou MD PhD ${ }^{1}$, \\ Efthimia Alexopoulou MD PhD², Konstantinos N Priftis MD PhD ${ }^{3}$
}

\begin{abstract}
A Fretzayas, M Moustaki, P Nicolaidou, E Alexopoulou, KN Priftis. Transient elevation of the ipsilateral hemidiaphragm associated with pneumonia. Can Respir J 2011;18(4):e66-e67.

Seventeen children with lobar or segmental pneumonia and ispilateral elevation of the diaphragm are described. These children did not differ significantly with respect to clinical and laboratory findings from their counterparts with pneumonia but without elevation of the hemidiaphragm. The elevation was transient and resolved by the time the repeat chest $\mathrm{x}$-ray was taken six to eight weeks later.
\end{abstract}

Key Words: Diaphragm; Eventration; Pneumonia

Cuntration of the diaphragm, congenital or acquired, is seen in Echildren of all ages (1). The present report describes 17 children with lobar or segmental pneumonia with elevation of the regional hemidiaphragm. The affected hemidiaphragm was considered to be elevated if it was located at least 1.5 intercostal spaces higher than the other side.

The clinical series comprised 17 children (11 males) eight months to 13 years of age experiencing a first episode of lobar or segmental pneumonia and elevation of the regional diaphragm (Figure 1) who were admitted to the Attikon University Hospital (Athens, Greece) during a two-year period. During the same period, 294 children (153 males) one month to 14 years of age were admitted with pneumonia; thus, children with hemidiaphragmatic elevation represented $6 \%$ of the total population. For each patient presenting with pneumonia and evidence of diaphragmatic elevation in the next admission, a patient of the same sex with pneumonia but without elevation served as a control. The two groups were not different with respect to age $(52 \pm 29.6$ months versus $49.4 \pm 39.1$ months), and clinical and laboratory findings. More specifically, fever was a common finding in both groups (mean duration of fever before admission was $3.2 \pm 2.6$ versus $2.7 \pm 1.6$ days). There were no respiratory distress symptoms and no paradoxical respiration either in case subjects or in controls. Pneumonia was right sided in eight children with diaphragmatic elevation, and bilateral in one who exhibited only right-sided elevation of the hemidiaphragm (Table 1). There was no history of previous disorders predisposing to hemidiaphragm elevation. In 12 patients, consolidation was identified in four upper lobes, one middle lobe and seven lower lobes, whereas consolidations were localized in more than one lobe of five patients with elevated hemidiaphragms. Similarly, the distribution of consolidation in the control group was one upper lobe, three middle lobe and seven lower lobes, with six affecting more than one lobe. Hilar adenopathy regional to consolidation or bilateral was evident in 10 patients with elevation of the hemidiaphragm and in eight controls. There was no difference with respect to white blood cell count, neutrophil and C-reactive protein levels, or erythrocyte sedimentation rate between the two groups. Pneumococcus antigen in urine samples was isolated in nine patients with elevated hemidiaphragm and in seven controls. In all children, the initial chest $\mathrm{x}$-ray was repeated six to eight weeks later, which showed resolution of the consolidation and of the diaphragmatic elevation.

\section{Une surélévation transitoire de l'hémidiaphragme ipsilatéral associée à la pneumonie}

Est exposé le cas de 17 enfants atteint d'une pneumonie lobaire ou segmentaire présentant une surélévation dus diaphragme ipsilatéral. L'état de ces enfants ne différait pas de manière significative de celui de leurs homologues atteints d'une simple pneumonie pour ce qui est des observations en laboratoire et en clinique, mais ces derniers ne présentaient pas d'élévation de l'hémidiaphragme. Cette surélévation, transitoire, s'était résorbée lors de la prise d'une nouvelle radiographie pulmonaire de six à huit semaines plus tard.

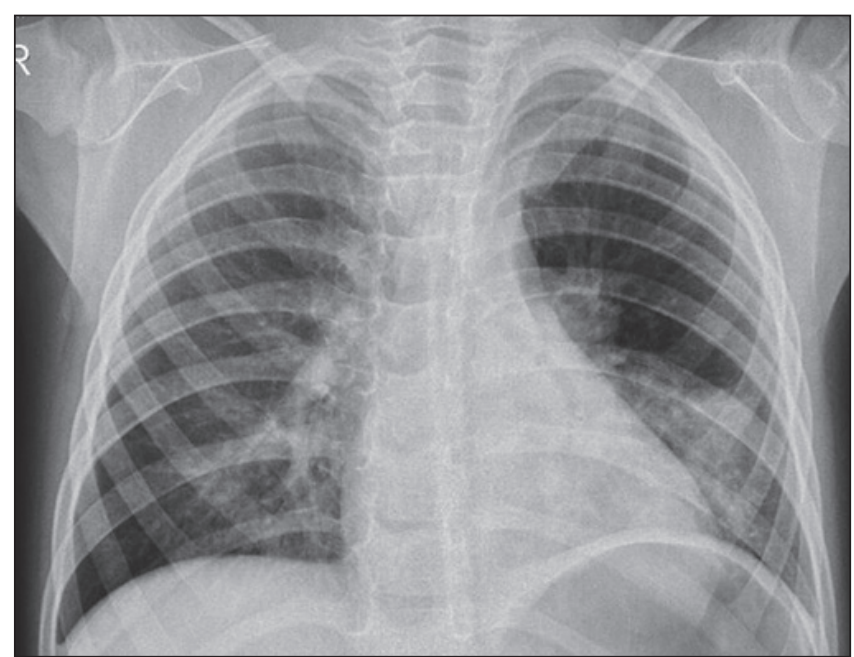

Figure 1) Chest $x$-ray showing right upper lobe consolidation with ipsilateral elevation of the diaphragm

TABLE 1

Location of consolidation in children with elevation of the hemidiaphragm

\begin{tabular}{lll}
\hline $\begin{array}{l}\text { Side of } \\
\text { pneumonia }\end{array}$ & $\begin{array}{l}\text { Location of } \\
\text { consolidation }\end{array}$ & $\begin{array}{l}\text { Side of } \\
\text { elevated diaphragm }\end{array}$ \\
\hline Right $(n=8)$ & 2 upper & Right \\
& 1 middle & \\
& 2 lower & \\
& 2 upper and middle & \\
& 1 upper and lower & \\
& 2 upper & Left \\
& 5 lower & \\
& 1 upper and lower & \\
& 1 Right lower and & Right \\
& left upper & \\
\hline
\end{tabular}

13rd Department of Pediatrics; ${ }^{2}$ Department of Radiology, "Attikon" University Hospital, University of Athens; ${ }^{3}$ Department of Allergy and Pulmonology, "Penteli" Children's Hospital, Athens, Greece

Correspondence: Dr Andrew Fretzayas, University of Athens, School of Medicine, "Attikon" University Hospital, 3rd Department of Pediatrics,

1 Rimini Street, Haidari 12462 Athens, Greece. Telephone 00302105831299, fax 00302105832229, e-mail mar.moustaki@gmail.com 
Lobar pneumonia may occasionally mimic segmental eventration. This was not the case in our series because even children presenting with pneumonia of the upper lobe had evidence of elevation. The treatment of eventration depends entirely on the symptoms (1) and, given that the patients were not experiencing respiratory distress symptoms, we did not proceed to further evaluation with fluoroscopy or specific conservative management. Diaphragmatic eventration predisposes to recurrent pneumonia (2); however, our patients had no history of previous pneumonia, whereas the elevation resolved in the repeat chest $\mathrm{x}$-ray taken six to eight weeks later. The etiology and mechanism of the condition is unknown. It is possible that abnormal lung compliance due to inflammation resulted in the transient elevation of the diaphragm. It may also be caused by dyskinesia or neuromuscular dysfunction related to the infectious insult (3). In 1950, Freedman (4) initially associated pneumonia with unilateral paralysis of the diaphragm. He reported six relevant cases, with diaphragmatic paralysis occurring in four at a mean of four weeks after the onset of

\section{REFERENCES}

1. Wayne ER, Campbell JB, Burrington JD, et al. Eventration of the diaphragm. J Pediatr Surg 1974;9:643-51.

2. Tiryaki T, Livanelioglou Z, Atayurt $\mathrm{H}$. Eventration of the diaphragm Asian J Surg 2006;29:8-10.

3. Yeb HC, Halton KP, Gray CE. Anatomic variations and abnormalities in the diaphragm seen with US. Radiographics 1990;10:1019-30.

4. Freedman B. Unilateral paralysis of the diaphragm and larynx associated with inflammatory lung disease. Thorax 1950;5:169-82. the acute illness. He attributed the paralysis of the diaphragm either to toxic or inflammatory neuritis of the phrenic nerve or to toxic or inflammatory diaphragmatitis.

Exclusively right diaphragmatic hernia has also been described following group B streptococcal pneumonia and sepsis $(5,6)$. However, these patients were mechanically ventilated and there were descriptions of necrotic, inflammatory erosion of the right diaphragm. It should also be mentioned that this causal link was refuted by Jain et al (7), who described a child with antenatally documented right diaphragmatic eventration who subsequently developed a beta-hemolytic streptococcal infection. It seems, therefore, that the presented cases comprised a different entity, not well described until now.

\section{CONCLUSION}

Diaphragmatic elevation is always transient in nature and is not uncommon in children with pneumonia. It is a benign, self-limited condition with no need for specific management.

5. Suresh BR, Rios A, Brion LP, et al. Delayed onset right sided diaphragmatic hernia secondary to group B streptococcal infection. Pediatr Infect Dis J 1991;10:166-8.

6. Handa N, Sulta S, Shono T, et al. Right sided diaphragmatic hernia following group B streptococcal pneumonia and sepsis. J Pediatr Surg 1992;27:764-6.

7. Jain M, Ford WDA, Hayward C. Beta haemolytic streptococcal infection does not cause right diaphragmatic eventration. Pediatr Surg Int 1997;12:188-9. 


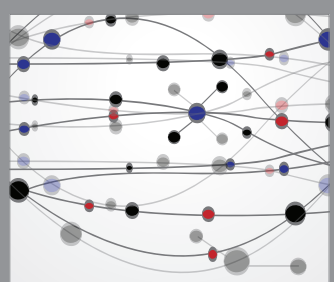

The Scientific World Journal
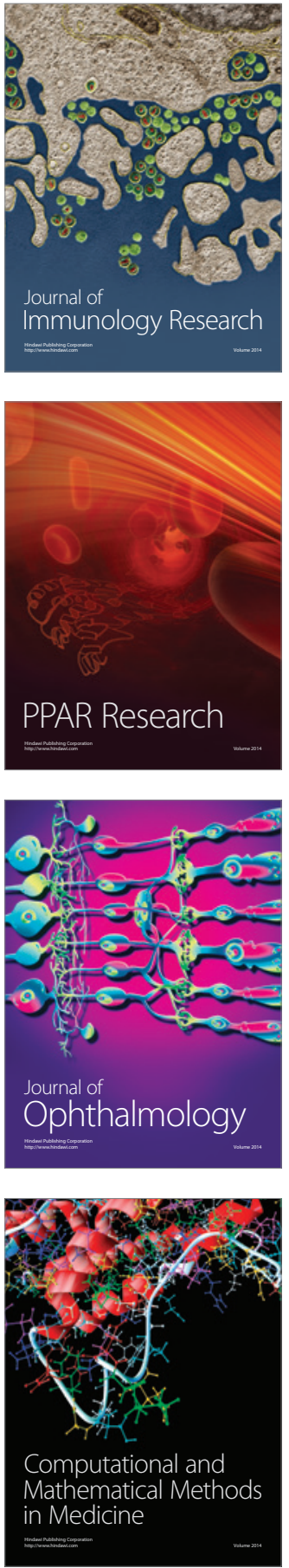

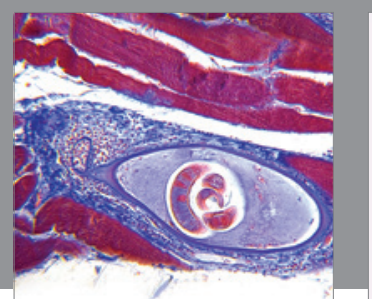

Gastroenterology Research and Practice

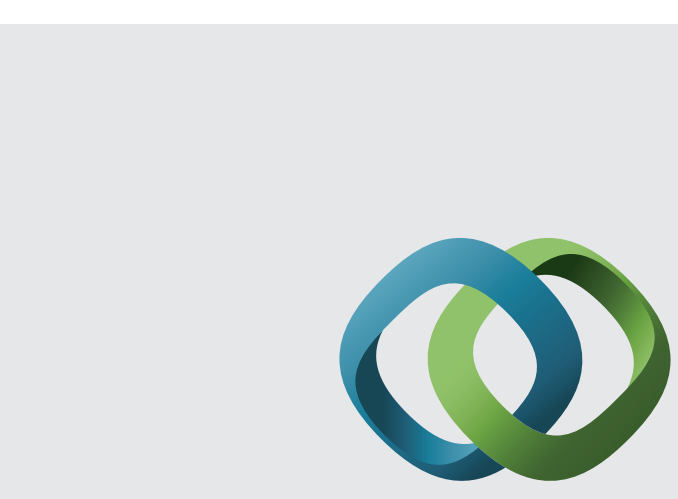

\section{Hindawi}

Submit your manuscripts at

http://www.hindawi.com
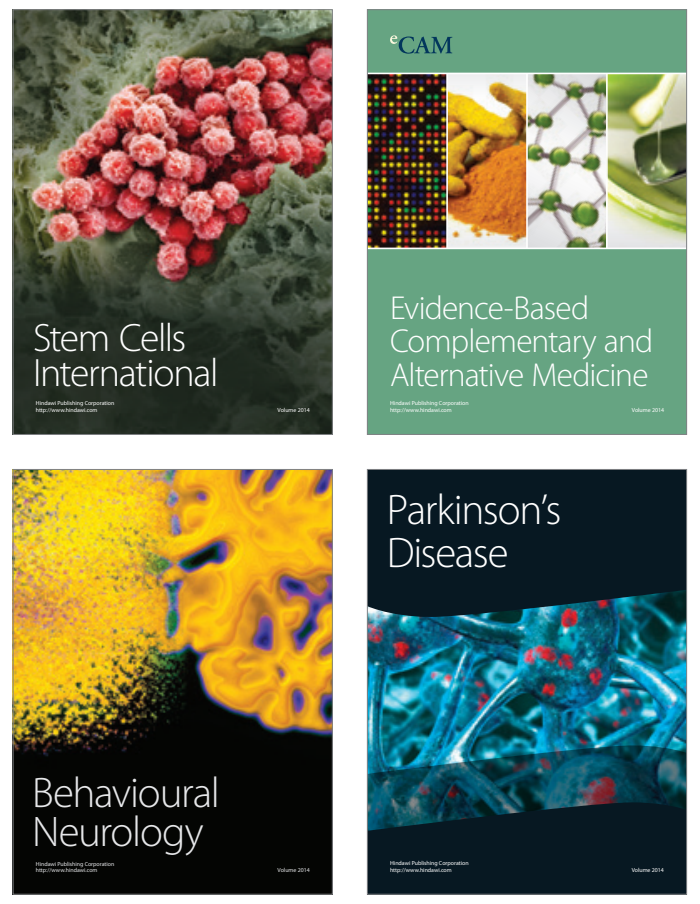
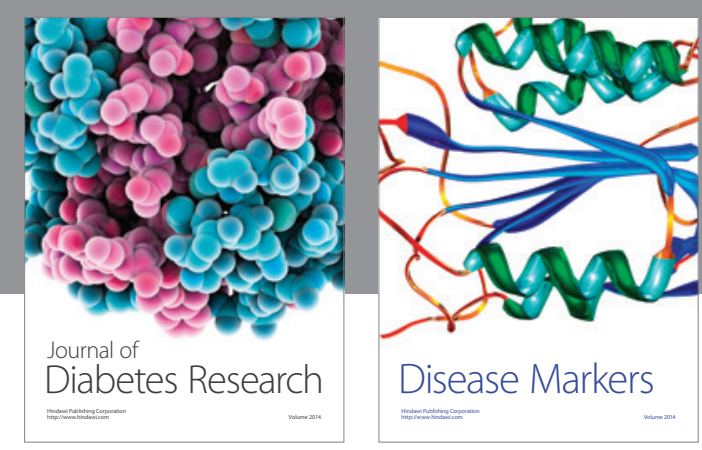

Disease Markers
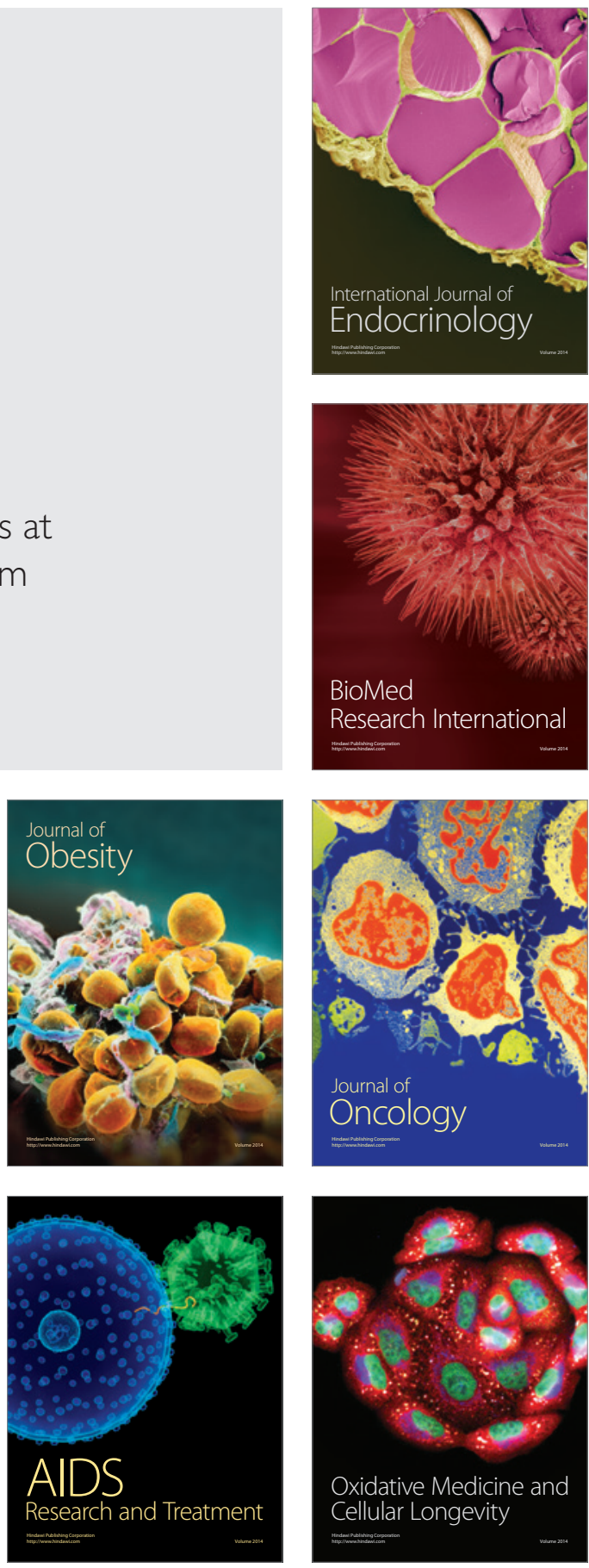